\title{
THE INFLUENCE OF SIMULATION METHOD AT SOCIAL SCIENCE LEARNING AS DISASTER MITIGATION EDUCATION OF MOUNT KELUD IN KEDIRI ELEMENTARY SCHOOL
}

\author{
Sandra Diah Ayu Pitaloka ${ }^{1}$, Tera Noviantiningtyas Ripto Saputri ${ }^{2}$ \\ 1,2Universitas Nusantara PGRI Kediri, Kediri, Indonesia \\ ${ }^{1}$ sandradiahayupitaloka@gmail.com, ${ }^{2}$ Teranovianti114@gmail.com
}

\begin{abstract}
The 2013 curriculum emphasizes learning using the scientific approach. In fact, many teachers still use conventional learning methods so that it impacts on student activity in the learning process. Moreover, the material taught is not related to concrete situations. The simulation method can be used to improve student learning outcomes in 4th grade in social science KD 4.2. The purpose of this study was to determine the effect of the simulation method on the ability to distinguish regions affected by the Mount Kelud eruption and to know the effect of the simulation method on the ability to demonstrate the mitigation efforts of the Mount Kelud eruption as a volcano in elementary school students in Kediri. The results of this study indicated: (1) based on the test results obtained $t_{\text {count }}=9.531>t_{\text {table }}=2.032$ with a significance level of 0.05 , there were differences in the results of the average pre-test with post-test which meant that there was an influence of using the simulation method on the ability of students to distinguish regions affected by the eruption of Mount Kelud; (2) based on the test results obtained $t_{\text {count }}=12.063>t_{\text {table }}=2.032$ with a significance level of 0.05, there were differences in the results of the average non-simulation with simulation, which meant that there was an influence of using the simulation method on the ability to demonstrate mitigation efforts in eruption of the Kelud as a volcano.
\end{abstract}

Keywords: learning methods, disaster mitigation, elementary school

\section{PENGARUH METODE SIMULASI PADA PEMBELAJARAN IPS SEBAGAI PENDIDIKAN MITIGASI BENCANA LETUSAN GUNUNG KELUD DI SEKOLAH DASAR KEDIRI}

\begin{abstract}
ABSTRAK
Penelitian ini membahas tentang metode pembelajaran yang digunakan guru pada saat Kurikulum 2013 menekankan pembelajaran menggunakan pendekatan scientific approach. Pada kenyataannya banyak guru yang masih menggunakan metode pembelajaran konvensional, sehingga berdampak pada keaktifan siswa dalam proses pembelajaran. Terlebih lagi materi yang diajarkan tidak dikaitkan dengan situasi konkrit. Metode simulasi dapat digunakan untuk meningkatkan hasil belajar siswa kelas 4 pada pembelajaran IPS KD 4.2. Tujuan penelitian ini adalah untuk mengetahui pengaruh metode simulasi terhadap kemampuan membedakan wilayah yang terkena dampak bencana letusan gunung kelud dan mengetahui pengaruh metode simulasi terhadap kemampuan mendemonstrasikan upaya mitigasi bencana letusan gunung kelud sebagai gunung berapi pada siswa sekolah dasar di Kediri. Hasil penelitian ini menunjukkan hasil 1. berdasarkan hasil uji diperoleh nilai $t_{\text {hitung }}=9.531>$ nilai $t_{\text {tabel }}=2.032$ dengan taraf signifikansi 0.05 maka ada perbedaan hasil rata-rata pre test dengan post test yang artinya ada pengaruh penggunaan metode simulasi terhadap kemampuan siswa dalam membedakan wilayah yang terkena dampak bencana letusan gunung kelud. 2. berdasarkan hasil uji diperoleh nilai $\mathrm{t}_{\text {hitung }}=12.063>$ nilai $\mathrm{t}_{\text {tabel }}=$ 2.032 dengan taraf signifikansi 0.05 maka ada perbedaan hasil rata-rata non simulasi dengan simulasi yang artinya ada pengaruh penggunaan metode simulasi terhadap kemampuan mendemonstrasikan upaya mitigasi bencana letusan gunung kelud sebagai gunung berapi.
\end{abstract}

Kata Kunci: metode pembelajaran, mitigasi bencana, sekolah dasar

\begin{tabular}{|c|c|c|}
\hline Submitted & Accepted & Published \\
\hline 01 Mei 2020 & 17 Juni 2020 & 21 Juli 2020 \\
\hline
\end{tabular}

\begin{tabular}{|l|c|c|c|}
\hline Citation & $:$ & $\begin{array}{c}\text { Pitaloka, S.D.A., \& Saputri, T.N.R. (2020). The Influence Of Simulation Method At Social Science Learning As Disaster } \\
\text { Mitigation Education Of Mount Kelud In Kediri Elementary School. Jurnal PAJAR (Pendidikan dan } \\
\text { Pengajaran), 4(4), 653-662. DOI : http://dx.doi.org/10.33578/pir.v4i2.8010. }\end{array}$ \\
\hline
\end{tabular}

\section{PENDAHULUAN}

Siswa sekolah dasar merupakan kelompok anak-anak yang paling rentan menjadi korban bencana alam. Pemahaman mengenai mitigasi bencana pada siswa pendidikan dasar merupakan salah satu solusi yang perlu dilakukan di Indonesia, guna mengurangi terjadinya bencana 
yang mengakibatkan kematian dan kecelakaan pada anak-anak di bawah umur 15 tahun. Jumlah kematian anak-anak yang sangat tinggi serta mengalami stress dan trauma tidak akan terjadi, apabila dari awal anak-anak dibentuk dengan konsep pemahaman akan mitigasi bencana. Dilansir dari tribunnews.com pada tanggal $12 \mathrm{Mei}$ 2020, ketika terjadi letusan gunung kelud sebanyak 59 ribu penduduk di empat kecamatan Kabupaten Kediri, terancam terkena dampak letusan Gunung Kelud. Warga terdampak erupsi Gunung Kelud ini meliputi wilayah Kecamatan Ngancar, Puncu, Plosoklaten, dan Kepung. Diantara warga yang terkena dampak letusan Gunung Kelud mayoritas orang dewasa dan anakanak. Anak-anak yang memiliki pengetahuan tentang cara penyelamatan diri dalam menghadapi bahaya, akan menjadi lebih mampu dan memiliki kepercayaan diri yang positif tanpa merasa ketakutan dan stress (Nugraha, 2018). Pendidikan mitigasi bencana dapat digunakan sebagai bekal siswa ketika siswa dihadapakan pada kondisi sedang terjadi bencana (Nurjanah, 2015). Inti pembelajaran pada kurikulum 2013 ada pada upaya penyederhanaan dan sifatnya yang tematikinstegratif. Kurikulum 2013 disiapkan untuk mencetak generasi yang siap dalam menghadapai tantangan masa depan. Oleh karena itu, kurikulum disusun untuk mengantisipasi masa depan. Kurikulum 2013 bertujuan supaya peserta didik memiliki keterampilan yang lebih baik dalam melakukan kegiatan observasi, bertanya, bernalar dan mengkomunikasikan apa yang di dapat setelah menerima materi pelajaran. Dalam kurikulum
2013 obyek pembelajarannya adalah: fenomena alam, sosial, seni, dan budaya. Melalui pendekatan tersebut diharapkan peserta didik memiliki kompetensi sikap, keterampilan, dan pengetahuan jauh lebih baik. Kurikulum 2013 merupakan kurikulum bebasis karakter dan kompetensi. Selain itu, kurikulum 2013 juga sebagai praksis kontekstual yaitu perluasan dari konsep kurikulum sebagai sebuah proses dengan penambahan perlunya komitmen bersama antar pelaku Pendidikan dan kegiatan-kegiatan yang diperlukan untuk mencapai target tertentu. Alur dari pendekatan tersebut adalah materi - proses produk. Penguasaan materi pembelajaran didapatkan dari siklus aksi dan refleksi yang berkelanjutan (continuous action-refelction). Peran guru sangat penting dalam menghasilkan komitmen dari siswa untuk mencapai target yang telah diharapkan. Sehingga diperlukan sebuah tambahan pendekatan transdisipliner melalui tema pembelajaran yang bersifat kontekstual dengan sekitarnya untuk memastikan praksisnya relevan.

Pada kurikulum 2013 pada mata pelajaran IPS terdapat kompetensi dasar yang dapat disisipkan Pendidikan mitigasi bencana letusan gunung berapi. Tidak hanya aspek kognitif saja akan tetapi siswa diberi keterampilan bagaimana cara mengurangi resiko bahaya bencana gunung berapi. Untuk mencapai kompetensi dasar tersebut diperlukan adanya metode pembelajaran yang melibatkan siswa secara aktif dalam proses pembelajaran. Metode pembelajaran yang dimaksud adalah metode simulasi.

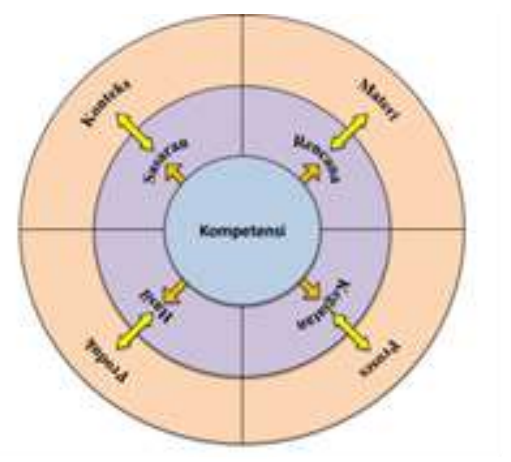

Gambar 1: Alur Kurikulum Sebagai Praksis Kontekstual. Diambil Dari Dokumen Kemendikbud 
Aadapun tujuan penelitian ini adalah sebagai berikut: 1) Untuk mengetahui pengaruh metode simulasi terhadap kemampuan membedakan wilayah yang terkena dampak bencana letusan gunung kelud pada siswa sekolah

\section{KAJIAN TEORETIS \\ Mitigasi Bencana}

Menurut UU No. 24 Tahun 2007 tentang Penanggulangan Bencana, mitigasi merupakan upaya-upaya yang dilakukan dengantujuan mengurangi risiko bencana, baik melalui pembangunan fisik maupun penyadaran, dan peningkatan kemampuan menghadapi ancaman bencana. Lebih lanjut, mitigasi adalah serangkaian upaya untuk mengurangi risiko bencana, baik melalui pembangunan fisik maupun penyadaran dan peningkatan kemampuan menghadapi ancaman bencana (Pasal 1 ayat 6 PP No 21 Tahun 2008 Tentang Penyelenggaraan Penanggulangan Bencana). Mitigasi adalah istilah yang digunakan untuk menunjuk pada semua tindakan untuk mengurangi dampak dari suatu bencana yang dapat dilakukan sebelum bencana itu terjadi, termasuk kesiapan dan tindakan-tindakan untuk mengurangi resiko-resiko yang terkait dengan bahaya-bahaya karena ulah manusia dan bahaya alam yang sudah diketahui dan proses perencanaan untuk respon yang efektif terhadap bencana-bencana yang benar-benar terjadi (Nugraha, 2018).

\section{Gunung Berapi}

Pada buku saku tanggap, tangkas, tangguh menghadapi bencana yang diterbitkan oleh BNPB terdapat dua jenis bahaya erupsi gunungapi yaitu bahaya primer dan sekunder. Bahaya gunung api yang pertama adalah awan panas. Awan panas merupakan aliran material vulkanik panas yang terdiri dari batuan berat dan ringan serta lava yang massif yang pergerakannya dipengaruhi oleh gravitasi. Awan panas cenderung mengalir melalui dasar di Kediri; 2) Untuk mengetahui pengaruh metode simulasi terhadap kemampuan mendemonstrasikan upaya mitigasi bencana letusan gunung kelud sebagai gunung berapi pada siswa sekolah dasar di Kediri.

lembah. Bahaya yang kedua adalah aliran lava, merupakan magma yang meleleh ke permukaan bumi melalui rekahan yang memiliki suhu lebih dari 10. Terdapat dua jenis bahaya erupsi gunungapi yaitu bahaya primer dan sekunder. Bahaya gunung api yang pertama adalah awan panas, Awan panas cenderung mengalir melalui lembah. Bahaya yang kedua adalah aliran lava, merupakan magma yang meleleh ke permukaan bumi melalui rekahan yang memiliki suhu lebih dari $.000^{\circ} \mathrm{C}$ dan dapat merusak berbagai bentuk infrastruktur. Bahaya yang ketiga adalah gas beracun yang berasal dari gas vulkanik. Gas ini bersifat sangat mematikan sehingga apabila terhirup dalam tubuh dapat menyebabkan kematian. Gas tersebut tersusun atas $\mathrm{CO} 2, \mathrm{SO}$, $\mathrm{Rn}, \mathrm{H} 2 \mathrm{~S}, \mathrm{HCl}, \mathrm{HF}, \mathrm{H} 2 \mathrm{SO} 4$. Gas vulkanik biasanya tidak berwarna dan tidak berbau. Bahaya yang keempat adalah lontaran material yang terjadi saat letusan magmatic berlangsung. Suhu saat letusan mencapai $200{ }^{\circ} \mathrm{C}$ dengan diameter lebih dari $20 \mathrm{~cm}$ dengan daya lontar ratusan kilometer. Bahaya yang kelima adalah hujan abu. Material abu sangat halus sehingga mudah terbawa oleh angin. Bahaya yang keenam adalah lahar letusan terjal pada gunung berapi yang memiliki danau kawah yang terjadi secara bersamaan saat letusan sehingga air yang bercampur material lepas dari gunung berapi dan mengalir dalam bentuk banjir lahar.

Terdapat beberapa hal yang harus diketahui mengenai ancaman dan bahaya erupsi gunung api seperti tingkat status gunung api (level) dan Kawasan Rawan Bencana (KRB). 
Jurnal PAJAR (Pendidikan dan Pengajaran)

Volume 4 Nomor 4 Juli 2020 | ISSN Cetak : 2580 - 8435 | ISSN Online : 2614 - 1337

DOI : http://dx.doi.org/10.33578/pir.v4i2.8010

\begin{tabular}{|c|c|c|}
\hline $\begin{array}{l}\text { Tingkat Status } \\
\text { (Level) }\end{array}$ & Istilah Dalam Bahasa & Penjelasan \\
\hline $\mathrm{I}$ & Normal & $\begin{array}{l}\text { Aktivitas yang ditunjukan gunungapi melalui pengamatan } \\
\text { hasil visual, tingkat gempa, dan gejala-gejala vulkanik tidak } \\
\text { memperlihatkan adanya aktivitas. }\end{array}$ \\
\hline II & Siaga & $\begin{array}{l}\text { Terdapat peningkatan aktivitas berupa kelainan yang terlihat } \\
\text { secara visual atau pada hasil pemeriksaan kawah, tingkat } \\
\text { gempa, dan gejala vulkanik lain. }\end{array}$ \\
\hline III & Waspada & $\begin{array}{l}\text { Aktivitas gunungapi mengalami peningkatan yang semakin } \\
\text { tinggi. Hasil pengamatan visual atau pemeriksaan kawah, } \\
\text { tingkat gempa dan metode lain menggambarkan aktivitas yang } \\
\text { semakin tinggi dan cenderung diikuti oleh letusan. }\end{array}$ \\
\hline IV & Awas & $\begin{array}{l}\text { Tingkatan terakhir sebelum letusan utama yang mana letusan } \\
\text { awal terjadi berupa abu atau asap dan berdasarkananalisis data } \\
\text { pengamatan kondisi ini akan segera diikuti oleh letusan } \\
\text { utama. }\end{array}$ \\
\hline Tingkat & & Penjelasan \\
\hline \multirow[t]{2}{*}{ KRBI } & \multicolumn{2}{|c|}{$\begin{array}{l}\text { KRB I merupakan area yang berpotensi terkena lahar, tertimpa material baik berupa } \\
\text { hujan abu, atau air dengan kadar keasaman yang tinggi. Jika letusan membesar, area } \\
\text { ini berpotensi terkena awan panas dan material jatuhan berupa hujan abu lebat serta } \\
\text { lontaran batu pijar. Area tersebut terbagi menjadi dua, yaitu: }\end{array}$} \\
\hline & 2) Kawas & $\begin{array}{l}\mathrm{n} \text { terhadap lahar yang mana terletak di sepanjang lembah dan } \\
\text { ungai terutama yang berasal dari daerah puncak. } \\
\text { cawan terhadap hujan abu tanpa memperhitungkan arah tiupan }\end{array}$ \\
\hline \multirow[t]{3}{*}{ KRB II } & \multicolumn{2}{|c|}{$\begin{array}{l}\text { KRB II merupakan area yang berpotensi terkena awan panas, aliran lava, lontaran } \\
\text { batu pijar atau guguran lava, hujan abu lebat, hujan lumpur panas, aliran lahar, dan } \\
\text { gas beracun. Area ini dibedakan menjadi dua, yaitu: }\end{array}$} \\
\hline & $\begin{array}{l}\text { gas beracun. Arec } \\
\text { 1) Kawas } \\
\text { lahar. }\end{array}$ & $\begin{array}{l}\text { awan terhadap awan panas, aliran lava, guguran lava, aliran } \\
\text { gas beracun terutama daerah hulu. }\end{array}$ \\
\hline & $\begin{array}{l}\text { 2) Kawas } \\
\text { lumpu }\end{array}$ & $\begin{array}{l}\text { cawan terhadap hujan abu lebat, lontaran batu pijar atau hujan } \\
\text { nas. }\end{array}$ \\
\hline KRB III & \multicolumn{2}{|c|}{$\begin{array}{l}\text { KRB III merupakan area yang memiliki potensi paling tinggi untuk terkena awan } \\
\text { panas, aliran lava, guguran lava, lontaran batu (pijar), atau gas beracun. Area ini } \\
\text { meliputi daerah puncak gunungapi dan sekitar. }\end{array}$} \\
\hline
\end{tabular}

Kediri merupakan daerah yang terkena dampak dari letusan gunung api Kelud. Berikut gambar peta wilayah yang terkena dampak gunung api Kelud. 


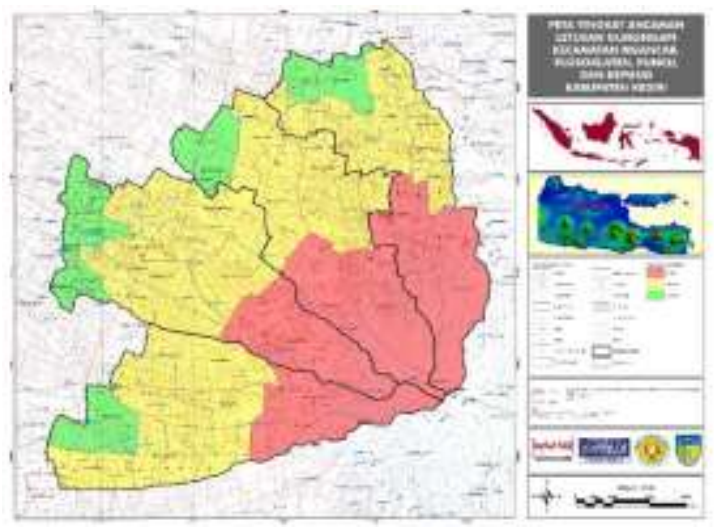

Gambar 2. wilayah kediri yang terkena dampak gunung api kelud Source: https://jawatimuran.wordpress.com/2014/09/29/pemetaan-kawasan-risiko-bencana-gunung-

\section{kelud/}

Metode Simulasi Sebagai Pendidikan Mitigasi Bencana di Sekolah Dasar

Metode pembelajaran adalah suatu cara yang dipergunakan oleh guru yang disusun dalam bentuk kegiatan nyata untuk menyampaikan materi pelajaran kepada siswa dengan tujuan pembelajaran yang dilakukan dapat dicapai dengan maksimal. Metode simulasi merupakan salah satu metode yang dapat diterapkan pada siswa untuk melakukan suatu hal dan siswa dapat merasakan bagaiman menghadapi situasi yang sebenarnya. Pada kurikulum 2013 mata pelajaran IPS yang terkait dengan masyarakat dapat menjadi media komunikasi yang cepat tersebar. Pendidikan mitigasi bencana dapat disisipkan pada pembelajaran IPS kelas 4 dengan KD 4.2 Mengidentifikasi karakteristik ruang dan pemanfaatan sumber daya alam untuk kesejahteraan masyarakat dari tingkat

\section{METODE PENELITIAN}

\section{Populasi dan Sampel Penelitian}

Populasi dalam penelitian ini adalah siswa SD yang ada di kediri dengan sampel penelitian SD Mojoroto 2 yang berjumlah 24 siswa dan SD Laboratorium UN PGRI Kediri yang berjumlah 11 kota/kabupaten sampai tingkat provinsi dan proses pembelajaran di dukung media audio-visual dan google maps.

Adapaun langkah-langkah melakukan metode simulasi sebagai pendidikan mitigasi gunung kelud adalah sebagai berikut: 1) siswa mengamati power point yang telah dibuat oleh peneliti; 2) siswa mengamati wilayah yang terkena dampak letusan gunung kelud; 3) siswa berlatih mewarnai wilayah yang terkena dampak letusan gunung kelud; 4) siswa bersama guru melakukan tanya jawab terkait upaya apa yang dapat dilakukan untuk mengatasi letusan gunung kelud; 5) siswa mengamati video simulasi bencana letusan gunung berapi (video yang dibuat oleh BNPB); 6) setelah siswa mengamati video, guru memberikan aba-aba untuk latihan simulasi dimulai; 7) siswa melakukan simulasi secara berkelompok.

siswa. Dengan demikian jumlah keseluruhan responden adalah 35 siswa.

\section{Tempat dan Objek Penelitian}

Penelitian ini dilaksanakan di sekolah dasar yang ada di Kediri yaitu SDN Mojoroto 2 
dan SD Laboratorium UN PGRI Kediri. Penelitian ini dilakukan pada bulan Februari. Objek penelitian ini adalah dengan menggunakan metode simulasi sebagai pendidikan mitigasi pada mata pelajaran IPS kelas 4.

\section{Metode Pengumpulan Data}

Penelitian ini menggunakan pendekatan kuantitatif dengan metode deskriptif. Penelitian ini berjenis kuantitatif karena akan diberikan nilai berupa angka atau skor. Metode deskriptif merupakan metode yang mendeskripsikan dengan sebuah fenomena. Fenomena dalam penelitian ini dalam bentuk sebuah aktivitas unjuk kerja siswa yaitu mensimulasikan upaya mitigasi bencana di wilayah gunung kelud. Pada penelitian ini sumber data yang menjadi acuan untuk menghasilkan data penelitian secara kuantitatif tentang kemampuan siswa dalam mengidentifikasi karakteristik ruang gunung kelud sebagai upaya mitigasi bencana adalah berasal dari nilai post test siswa setelah diberi perlakuan dan simulasi mitigasi bencana yang dipraktikan siswa pada mata pelajaran IPS. Data berupa angka/skor yang didasarkan pada hasil post test siswa dan hasil unjuk kerja siswa melalui kegiatan simulasi dengan pengembangan model mitigasi bencana. Dengan diperolehnya data berupa skor dapat diketahui tingkat pemahaman siswa terhadap mitigasi bencana letusan gunung kelud.

\section{Teknik Pengumpulan Data}

Penelitian ini menggunakan teknik peengumpulan data berupa hasil post test dan unjuk kerja siswa. Untuk mengumpulkan data berdasarkan hasil post test dilakukan dengan cara siswa menerima pembelajaran yang dilakukan setelah itu siswa mengerjakan soal refleksi sebagai evaluasi apakah siswa telah memahami pendidikan mitigasi bencana letusan gunung kelud. Selanjutnya untuk mengumpulkan data berupa unjuk kerja melalui kegiatan simulasi upaya mitigasi bencana gunung kelud dilakukan secara berkelompok. Setiap kelompok menentukan perannya masing-masing sesuai pengamatan video yang dibuat oleh BNPB yang berjudul "sahabat siaga: gunung meletus". Siswa mempersiapkan peralatan yang menunjang proses simulasi, siswa meniru peristiwa yang terdapat dalam video. Saat siswa mensimulasikan kegiatan mitigasi bencana, peneliti melakukan scoring atau menilai penampilan siswa.

\section{Teknik Analisis Data}

Teknik analisis data yang berupa nilai didapatkan dari hasil post test siswa dan data yang berupa skor didapatkan dari hasil unjuk kerja siswa yaitu siswa mensimulasikan kegiatan mitigasi bencana secara berkelompok. Skor bernilai 1 sampai 4, skor 1 untuk kriteria belum bisa mensimulasikan dengan baik, skor 2 untuk kriteria mensimulasikan kurang baik, skor 3 untuk kriteria mensimulasikan sudah cukup baik dan skor 4 untuk kriteria mensimulasikan dengan baik. Untuk menghasilkan nilai siswa maka digunakan rumus:

$\frac{\text { skor perolehan siswa }}{\text { skor maksimal }} \times 100$

dengan keterangan skor maksimal adalah 4 .

\section{Instrument Pengumpulan Data}

Instrumen pengumpulan data post test berupa lembar evaluasi sebanyak 10 pertanyaan sebagai refleksi pemahaman siswa sesudah menerima pembelajaran mitigasi bencana. Dan yang kedua menggunakan media video simulasi siaga bencana yang dibuat oleh pihak BNPB yang telah di upload di media youtube dan form penilaian kinerja atau unjuk kerja tentang penampilan siswa dalam mensimulasikan upaya mitigasi bencana letusan gunung kelud.

\section{Desain Penelitian}

Dalam penelitian ini menggunakan desain penelitian eksperimen, tidak dapat dipungkiri bahwa Negara Indonesia adalah negara yang rentan terjadi bencana. Maka dari permasalahan yang ada, metode simulasi diujicobakan dalam proses pembelajaran IPS kelas 4 tema 2 subtema 4 yang disisipkan dengan upaya mitigasi bencana. Dari pernyataan tersebut, dapat dibuat desain penelitian sebagai berikut: 
Metode simulasi upaya mitigasi bencana

\section{Kemampuan} mensimulasi
Hasil

\section{HASIL DAN PEMBAHASAN \\ Data Hasil Penelitian}

Berdasarkan penelitian dari Indriasari (2016) menunjukkan hasil pemberian metode simulasi siaga bencana gempa bumi memberikan pengaruh positif dengan kategori lemah terhadap kesiapsiagaan menghadapi bencana gempa bumi pada anak-anak dengan nilai probabilitas kesalahan <0.01. Nikmah (2016) metode simulasi sangat efektif diterapkan dalam pembelajaran siaga bencana gempa bumi. Hal tersebut dapat diketahui dari hasil perhitungan $\mathrm{t}_{\text {hitung }}=4.58$ dan $\mathrm{t}_{\text {tabel }}=2.120$ pada taraf signifikansi $5 \%$. Karena $t_{\text {hitung }}>t_{\text {tabel }}$ maka Ho diterima. Hal ini berarti ratarata nilai kelas eksperimen lebih besaar dari pada rata-rata nilai kelas kontro, sehingga dapat dikatakan bahwa pembeljaran pada kelas eksperimen lebih efektif daripada kelas kontrol.

Secara rinci data hasil penelitian akan dijelaskan pada tabel berikut:

Untuk indikator 1. membedakan wilayah yang terkena dampak bencana letusan gunung Kelud.

\section{Tabel 1. Paired Samples Statistics}

\section{Paired Samples Statistics}

\begin{tabular}{lll|l|r|r} 
& & \multicolumn{1}{c|}{ Mean } & $N$ & Std. Deviation & \multicolumn{1}{c}{ Std. Error Mean } \\
\hline Pair 1 & pre_test & 83.03 & 35 & 2.802 & .474 \\
\cline { 2 - 7 } & post_test & 89.20 & 35 & 3.505 & .592 \\
\hline
\end{tabular}

Berdasarkan nilai rata-rata hasil belajar yang diperoleh siswa SDN Mojoroto 2 dan SD Laboratorium UN PGRI Kediri menunjukkan hasil nilai pre test < post test yang artinya ada perbedaan rata-rata hasil belajar yang diperoleh siswa. Untuk mengetahui kebenaran adanya perbedaan maka dapat dilihat pada table paired sample test.

Tabel 2. Paired Samples Correlations

Paired Samples Correlations

\begin{tabular}{llr|r|r} 
& & Correlation & \multicolumn{2}{r}{ Sig. } \\
\hline Pair 1 & pre_test \& post_test & 35 & .278 & .106 \\
\hline
\end{tabular}

Berdasarkan hasil yang diperoleh menunjukkan hasil uji korelasi antara kedua variabel pre test dan post test diketahui nilai correlation sebesar 0.278 dengan nilai sig sebesar
0.106. Karena nilai sig. $0.106>$ probabilitas 0.05 maka dapat dikatakan bahwa tidak ada hubungan antara variabel pre test dengan variabel post test. 
Tabel 3. Paired Samples Test

\begin{tabular}{|c|c|c|c|c|c|c|c|c|c|}
\hline \multicolumn{10}{|c|}{ Paired Samples Test } \\
\hline \multicolumn{10}{|c|}{ Paired Differences } \\
\hline & & \multirow[b]{4}{*}{ Mean } & \multirow{4}{*}{$\begin{array}{c}\text { Std. } \\
\text { Deviation }\end{array}$} & \multirow{4}{*}{$\begin{array}{c}\text { Std. Error } \\
\text { Mean }\end{array}$} & \multirow{3}{*}{\multicolumn{2}{|c|}{$\begin{array}{c}\text { 95\% Confidence } \\
\text { Interval of the } \\
\text { Difference }\end{array}$}} & \multirow[b]{4}{*}{$\mathrm{t}$} & \multirow[b]{4}{*}{$\mathrm{df}$} & \multirow{4}{*}{$\begin{array}{l}\text { Sig. (2- } \\
\text { tailed) }\end{array}$} \\
\hline & & & & & & & & & \\
\hline & & & & & & & & & \\
\hline & & & & & Lower & Upper & & & \\
\hline Pair & pre_test - & -6.171 & 3.831 & .648 & -7.487 & -4.855 & -9.531 & 34 & .000 \\
\hline 1 & post_test & & & & & & & & \\
\hline
\end{tabular}

\section{Rumusan hipotesis penelitian}

Ho = tidak ada perbedaan hasil rata-rata pre test dengan post test yang artinya tidak ada pengaruh penggunaan metode simulasi terhadap kemampuan siswa dalam membedakan wilayah yang terkena dampak bencana letusan gunung kelud.

$\mathrm{Ha}=$ ada perbedaan hasil rata-rata pre test dengan post test yang artinya ada pengaruh penggunaan metode simulasi terhadap kemampuan siswa dalam membedakan wilayah yang terkena dampak bencana letusan gunung kelud.
Berdasarkan hasil uji paired samples test diperoleh nilai $t_{\text {hitung }}=9.531$ dan nilai $t_{\text {tabel }}=2.032$ dengan taraf signifikansi 0.05 . Karena $t_{\text {hitung }}>t_{\text {tabel }}$ maka Ho ditolak dan Ha diterima sehingga dapat disimpulkan bahwa ada perbedaan hasil rata-rata pre test dengan post test yang artinya ada pengaruh penggunaan metode simulasi terhadap kemampuan siswa dalam membedakan wilayah yang terkena dampak bencana letusan gunung kelud. Untuk indikator 2. mendemonstrasikan upaya mitigasi bencana letusan gunung kelud sebagai gunung berapi.

\section{Tabel 4. Paired Samples Statistics}

\section{Paired Samples Statistics}

\begin{tabular}{llr|r|r|r} 
& & Mean & $N$ & Std. Deviation & \multicolumn{2}{c}{ Std. Error Mean } \\
\hline Pair 1 & non_simulasi & 82.23 & 35 & 1.832 & .310 \\
\cline { 2 - 6 } & simulasi & 86.91 & 35 & 2.020 & .341 \\
\hline
\end{tabular}

Berdasarkan nilai rata-rata hasil belajar yang diperoleh siswa SDN Mojoroto 2 dan SD Laboratorium UN PGRI Kediri menunjukkan hasil nilai mean non simulasi < nilai mean simulasi yang artinya ada perbedaan rata-rata kemampuan siswa mendemontrasikan upaya mitigasi bencana. Untuk mengetahui kebenaran adanya perbedaan maka dapat dilihat pada tabel paired sample test. 


\section{Tabel 5. Paired samples correlations}

Paired Samples Correlations
\begin{tabular}{rrrrr}
\multicolumn{1}{c}{} & $\mathrm{N}$ & \multicolumn{1}{c}{ Correlation } & \multicolumn{1}{c}{ Sig. } \\
\hline Pair 1 & non_simulasi \& simulasi & 35 & $9+68.291$ & .089 \\
\hline
\end{tabular}

Berdasarkan hasil yang diperoleh menunjukkan hasil uji korelasi antara kedua variabel non simulasi dan simulasi diketahui nilai correlation sebesar 0.291 dengan nilai sig sebesar
0.089. Karena nilai sig. $0.089>$ probabilitas 0.05 maka dapat dikatakan bahwa tidak ada hubungan antara variabel non simulasi dengan variabel simulasi.

Tabel 6. Paired Samples Test

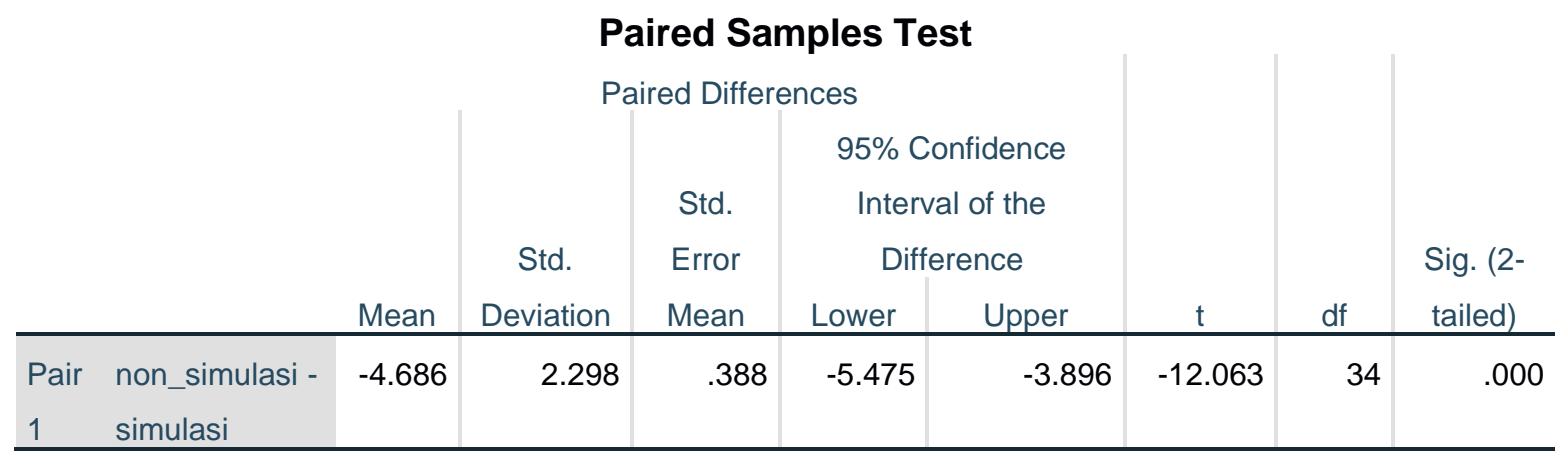

\section{Rumusan hipotesis penelitian}

Ho = tidak ada perbedaan hasil rata-rata non simulasi dengan simulasi yang artinya tidak ada pengaruh penggunaan metode simulasi terhadap kemampuan mendemonstrasikan upaya mitigasi bencana letusan gunung kelud sebagai gunung berapi.

$\mathrm{Ha}=$ ada perbedaan hasil rata-rata non simulasi dengan simulasi yang artinya ada pengaruh penggunaan metode simulasi terhadap kemampuan mendemonstrasikan upaya mitigasi bencana letusan gunung kelud sebagai gunung berapi.

Berdasarkan hasil uji paired samples test diperoleh nilai $\mathrm{t}_{\text {hitung }}=12.063$ dan nilai $\mathrm{t}_{\text {tabel }}=$ 2.032 dengan taraf signifikansi 0.05. Karena $t_{\text {hitung }}$ $>t_{\text {tabel }}$ maka Ho ditolak dan Ha diterima sehingga dapat disimpulkan bahwa ada perbedaan hasil rata-rata non simulasi dengan simulasi yang artinya ada pengaruh penggunaan metode simulasi terhadap kemampuan mendemonstrasikan upaya mitigasi bencana letusan gunung kelud sebagai gunung berapi.

perbedaan hasil rata-rata pre test dengan post test yang artinya ada pengaruh penggunaan metode simulasi terhadap kemampuan siswa dalam membedakan wilayah yang terkena dampak 
bencana letusan gunung kelud.

Berdasarkan hasil, diperoleh nilai thitung $=12.063$ dan nilai ttabel $=2.032$ dengan taraf signifikansi 0.05 . Karena thitung $>$ ttabel maka Ha diterima sehingga dapat disimpulkan bahwa ada perbedaan hasil rata-rata non simulasi dengan simulasi yang artinya ada pengaruh penggunaan metode simulasi terhadap kemampuan mendemonstrasikan upaya mitigasi bencana letusan gunung kelud sebagai gunung berapi.

Penggunaan metode simulasi dapat meningkatkan hasil belajar dan kemampuan mendemonstrasikan upaya pendidikan mitigasi

\section{UCAPAN TERIMA KASIH}

Ucapan terima kasih kami sampaikan kepada pihak-pihak yang telah memeberi dukungan berupa motivasi dan pihak yang telah membantu demi terlaksananya proses penelitian ini sehingga berjalan dengan lancar. Terima kasih

\section{DAFTAR PUSTAKA}

Ajuba, P. B. (2015). Studi Kebijakan Mitigasi Bencana Gunung Api Berbasis Kearifan Lingkungan di SDN Nglabak Srumbung Magelang. Skripsi. Fakultas Ilmu Pendidikan, Surakarta.

BNPB. (2017). Buku Saku Tanggap Tangkas Tangguh Menghadapi Bencana. Jakarta: Pusat Data, Informasi dan Humas Badan Nasional Penanggulangan Bencana

Indriasari, F. N. (2016). Pengaruh Metode Simuklasi Siaga Bencana Gempa Bumi Terhadap Kesiapsiagaan Anak di Yogyakarta. Jurnal Keperawatan Soedirman. 11 (3), 199-206

Nikmah, L. (2016). Implementasi Metode Simulasi Dalam Pembelajaran Siaga Bencana Gempa Bumi di SMA Negeri 1 Karanganom Klaten. Skripsi. Fakultas Ilmu Sosial, Semarang.

Nugroho, A. (2018). Pengembangan Model Pembelajaran Mitigasi Bencana Gunung Meletus di Sekolah Dasar Lereng Gunung Slamet. Jurnal Pengabdian Masyarakat. 1 (2), 51-54. bencana di lingkungan siswa sekolah dasar yang disisipkan pada pembelajaran IPS kelas 4, sehingga siswa mampu mengetahui kondisi pra bencana, sedang bencana dan pasca terjadinya bencana alam terutama bencana letusan gunung api. Diharapkan dengan penggunaan metode simulasi yang diterapkan pada proses pembelajaran dapat memberikan gambaran visual kepada siswa bagaimana terjadinya letusan gunung api dan apa saja yang dapat mereka lakukan serta mengurangi resiko korban bencana alam yang menimpa anak usia sekolah dasar.

kami tujukan kepada rektor, kepala prodi PGSD, dosen pembimbing serta rekan tim. Semoga artikel yang telah kami buat dapat memberi manfaat bagi yang membacanya.

Nurjanah, I. S. (2015). Penggunaan Metode Pembelajaran Simulasi Untuk Materi Kesiapsiagaan Bencana Gempa Bumi Siswa Kelas X IIS SMA Negeri 1 Tawangsari Kabupaten Sukoharjo Tahun Ajaran 2015/2016. Skripsi. Fakultas Keguruan dan Ilmu Pendidikan, Surakarta.

Setiono, A. N. (2014). Mitigasi Bencana Erupsi Gunungapi Merapi di Desa Dompol Kecamatan Kemalang Kabupaaten Klaten. Skripsi. Fakultas Keguruan dan Ilmu Pendidikan, Surakarta.

Setyawati, S., dkk. (2015). Kecerdasan Tradisional dalam Mitigasi Bencana Erupsi pada Masyarakat Lereng Baratdaya Gunungapi Merapi. Jurnal Ilmu-Ilmu Sosial. 12 (2), 100-110

Winarni, S., dkk. (2016). Upaya Pengurangan Risiko Bencana (Mitigasi) Letusan Gunung Kelud Oleh Masyarakat di Wilayah Kawasan Rawan Bencana (KRB) III Kabupaten Blitar. Junrnal Ners dan Kebidanan. 3 (3), 272-277. 